\title{
INFLUENCE OF TILLAGE SYSTEMS IN A LONG-TERM EXPERIMENT ON TRACK DEPTHS AND CROP YIELDS UNDER PANNONIAN CLIMATE
}

\section{Gerhard MOITZI ${ }^{1}$, Helmut WAGENTRISTL ${ }^{1}$, Peter LIEBHARD ${ }^{2}$, Reinhard NEUGSCHWANDTNER ${ }^{2}$}

University of Natural Resources and Life Sciences (BOKU), AUSTRIA

${ }^{1}$ Department of Crop Sciences, Experimental Farm Groß-Enzersdorf, Schloßhofer Straße 31, A-2301

Groß-Enzersdorf, AUSTRIA

${ }^{2}$ Department of Crop Science, Division of Agronomy, Konrad Lorenz-Straße 24, A-3430 Tulln an der

Donau, AUSTRIA

E-mail of corresponding author: gerhard.moitzi@boku.ac.at

Keywords: tillage systems, track depth, soil water content, Pannonian climate, winter wheat

\begin{abstract}
Based on a long-term experiment under Pannonian climate, the tillage effects on track depth, soil moisture content and grain yield of winter wheat in the vegetation period 2016/2017 are shown. The physical soil properties were measured in March 2017 indirectly: soil strength was measured through the track depth caused by a wheel load ballasted tractor with a rear wheel load of $13.7 \mathrm{kN}$. Soil moisture content was measured with a soil moisture meter at the depth of $5 \mathrm{~cm}$ after track depth measurement. No tillage resulted in the lowest track depth. Water content was highest in the conservation tillage systems, which had also a higher grain yield of winter wheat than the mouldboard-plough-system.
\end{abstract}

\section{INTRODUCTION}

Soil tillage systems can and should play an important role in solving future challenges in producing food. The effect of the tillage systems on yield depends mainly on climate and soil conditions. A global meta-analysis by Pittelkow et al. (2015) showed that conservation tillage in dry climates produce equivalent or greater yields than conventional tillage. The lower water losses and better water storage capacity are mainly responsible for the yield effects of conservation tillage systems (Thaler et al. 2012). Neugschwandtner et al. (2015) showed that in eastern Austria winter wheat yields were higher with ploughing than with no-tillage in years with a high amount of rainfall but did not differ between tillage treatments in dry years.

Brunotte et al. (2007) revealed in their experiments a better soil bearing capacity (expressed in lower track depths) under conservation tillage systems than in soil-turning systems.

This paper deals the influence of tillage systems under Pannonian climate conditions on the track depths (parameter for soil stability), soil water content and grain yield of winter wheat in the vegetation period 2016/2017.

\section{MATERIALS AND METHODS}

\section{Site description}

The experiment was established in 1996 at the Experimental Station of the University of Natural Resources and Life Sciences Vienna (BOKU) in Raasdorf (48 $14^{\prime} \mathrm{N}, 16^{\circ} 33^{\prime} \mathrm{E}$; $153 \mathrm{~m}$ a.s.l.). The field site is located in the east of Vienna (Austria) on the edge of the Marchfeld plain, which is an important crop production region in the north-western part of the Pannonian Basin. The silt loam soil is classified as a Chernozem of alluvial origin and is rich in calcareous sediments $\left(\mathrm{pHCaCl}_{2}\right.$ : 7.6 , soil organic carbon: $\left.2.3 \%\right)$. The mean annual temperature is $10.0^{\circ} \mathrm{C}$, the mean annual precipitation is $560 \mathrm{~mm}$ (19112015). Long-term precipitation pattern shows that the most rainfall occurs from May to 
September with monthly values above $55 \mathrm{~mm}$ and with the highest amount in June (72 $\mathrm{mm})$. Average temperature and precipitation during the vegetation period of winter wheat (from October 2016 until June 2017) were $7.6^{\circ} \mathrm{C}$ and $261.8 \mathrm{~mm}$.

\section{Experimental design and management}

The experiment is conducted in a split-plot design with four replications and involves two factors: tillage system is assigned to the main plots $(24 \times 40 \mathrm{~m})$ and crop rotation (A and B) to the subplots $(12 \times 40 \mathrm{~m})$. It started in the year 1996. In the period 19972017 , rotation A had a share of winter wheat of $50 \%$ winter wheat and rotation B of $45 \%$. Winter wheat was grown on rotation A and B in the year 2016/2017. The pre-crop of winter wheat in rotation A was maize and rotation B was soybean.

The purpose of the trial was to perform a long-term comparison of four different tillage systems: Mouldboard plough (MP), deep conservation tillage (CTd), shallow conservation tillage (CTs) and no-tillage (NT). The sequence of tillage operations are shown in Table 2. The technical working width of the four furrow reversible mouldboard plough was $1.7 \mathrm{~m}$ and for the other implements (wing sweep cultivator, subsoiler, pneumatic universal seed drill) $3.0 \mathrm{~m}$, respectively. The wing sweep cultivator had seven tines on two bars with a tine distance of $84 \mathrm{~cm}$ and a line distance of $42 \mathrm{~cm}$. Behind the tine bars three rotary hoes for crumbling and a wedge ring roller for crumbling and depth adjustment were mounted. The subsoiler had four fixed tines (tine distance: $75 \mathrm{~cm}$ ) with wings $(34 \mathrm{~cm}$ width) at the bottom and a roller harrow for depth adjustment. The pneumatic universal seed drill consisted of the pre-implement short disc harrow, which can be lifted up for seeding in NT.

Table 1. Tillage systems with used implements and working depth (in brackets)

\begin{tabular}{|c|c|c|c|c|}
\hline $\begin{array}{c}\text { Tillage } \\
\text { operation }\end{array}$ & $\begin{array}{c}\text { Mouldboard } \\
\text { plough (MP) }\end{array}$ & $\begin{array}{c}\text { Deep Conservation } \\
\text { tillage (CTd) }\end{array}$ & $\begin{array}{c}\text { Shallow } \\
\text { conservation } \\
\text { tillage (CTs) }\end{array}$ & $\begin{array}{c}\text { No-Tillage } \\
\text { (NT) }\end{array}$ \\
\hline $\begin{array}{c}\text { Stubble } \\
\text { cultivation }\end{array}$ & $\begin{array}{c}\text { Wing sweep } \\
\text { cultivator } \\
(5-8 \mathrm{~cm})\end{array}$ & $\begin{array}{c}\text { Wing sweep } \\
\text { cultivator } \\
(5-8 \mathrm{~cm})\end{array}$ & $\begin{array}{c}\text { Wing sweep } \\
\text { cultivator } \\
(5-8 \mathrm{~cm})\end{array}$ & - \\
\hline $\begin{array}{c}\text { Primary } \\
\text { tillage }\end{array}$ & $\begin{array}{c}\text { Mouldboard plough } \\
(25-30 \mathrm{~cm})\end{array}$ & $\begin{array}{c}\text { Wing sweep } \\
\text { cultivator } \\
(16-20 \mathrm{~cm})\end{array}$ & $\begin{array}{c}\text { Wing sweep } \\
\text { cultivator } \\
(8-10 \mathrm{~cm})\end{array}$ & - \\
\hline Subsoiler $(35 \mathrm{~cm})$ & Pneumatic universal \\
Seeding & $\begin{array}{c}\text { Pneumatic universal } \\
\text { seed drill }{ }^{1)}(3 \mathrm{~cm})\end{array}$ & $\begin{array}{c}\text { Pneumatic universal } \\
\text { seed drill }{ }^{1)}(3 \mathrm{~cm})\end{array}$ & $\begin{array}{c}\text { Pneumatic } \\
\text { universal seed } \\
\text { drill }{ }^{2)}(3 \mathrm{~cm})\end{array}$ \\
\hline
\end{tabular}

The combined chassis and packer unit after the short disc harrow is used for recompacting the soil before seeding with 24 double disc coulter in offset. The total weight of the pneumatic universal seed drill with the empty seed-hopper (3,000 L) was $4,550 \mathrm{~kg}$.Sowing, plant protection, fertilization and harvest were performed with regular farm machinery. Wheat was sown in mid-October with 320 germinable seeds $/ \mathrm{m}^{2}$. One herbicide application for broadleaf weed control was done in mid-April on all plots and on NT plot additionally with non-selective herbicides for weed control before sowing. The nitrogen fertilizer calcium ammonium nitrate (CAN, 27\%) was applied at a total of $130 \mathrm{~kg} \mathrm{~N} / \mathrm{ha}$, splitted in two applications. Harvest was performed with a plot combine harvester (Wintersteiger ${ }^{\circledR}$ Delta) with yield and moisture monitoring system (Harvest Master Classic GrainGage) at 12 $2^{\text {th }}$ July 2017. 


\section{Measuring track depth}

Track depth and soil moisture content were measured at $23^{\text {th }}$ March 2017. During the two weeks before $16 \mathrm{~mm}$ rainfall was recorded. Especially the soil of MP showed a crusty soil surface. A rear ballasted tractor with a with rear wheel load of $13.7 \mathrm{kN}$ $(=1400 \mathrm{~kg})$ was used (Figure 1). The narrow rear tires with the dimension 9.5-42 were adjusted with an inflation pressure of $300 \mathrm{kPa}$. The track depth measurement was carried out with a girder bridge and measuring stick according Schick 1991 (Figure 1).

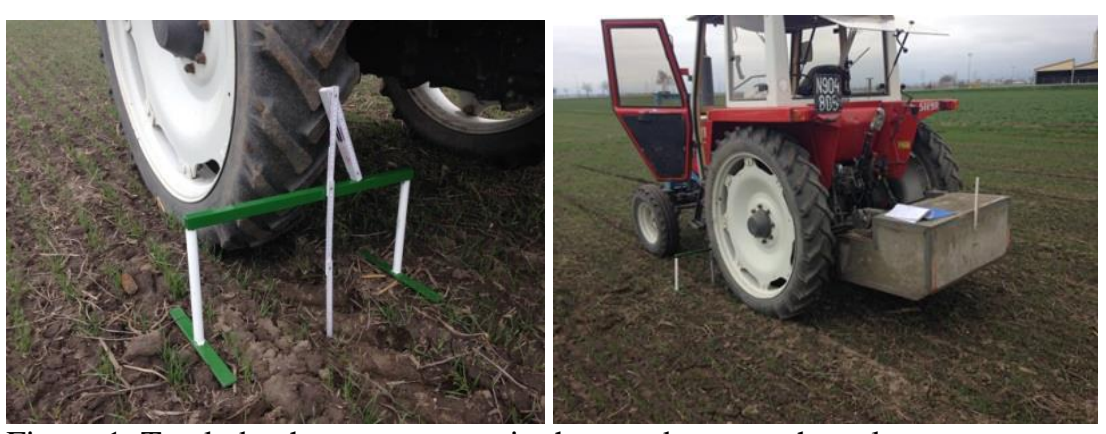

Figure 1. Track depth measurement in the area between the axle

From the plot edge the tractor was reversed $10 \mathrm{~m}$. On each track at the deepest tire print, two measurements were done in the area between axles. After $5 \mathrm{~m}$ reverse the measurement was repeated. 16 measurements per plot in four repetitions were made. Per treatment 64 measurements were taken. The soil moisture content was measured vertically with a soil moisture meter at the depth of $5 \mathrm{~cm} 28$ times per tillage treatment.

\section{Statistical analysis}

All analyses were conducted using IPM $^{\circledR}$ SPSS $^{\circledR}$ Statistics 21.The requirements for analysis of variance were tested with the Levene test and normal distribution of residues. One-factorial ANOVA tests were carried out for track depth, soil moisture content and grain yield. The multiple comparison test to separate means was carried out with the Student-Newman-Keuls procedure $(\mathrm{p}<0.05)$.

\section{RESU LTS}

\section{Track depth and moisture content}

NT had a significant lower track depth than in MP (Figure 1). CTs had in the same track depth level than MP. CTd showed the highest track depth, which can be explained by the better loosening effect with increased soil porosity through the wing sweep cultivator in comparison soil loosening with mouldboard plough.

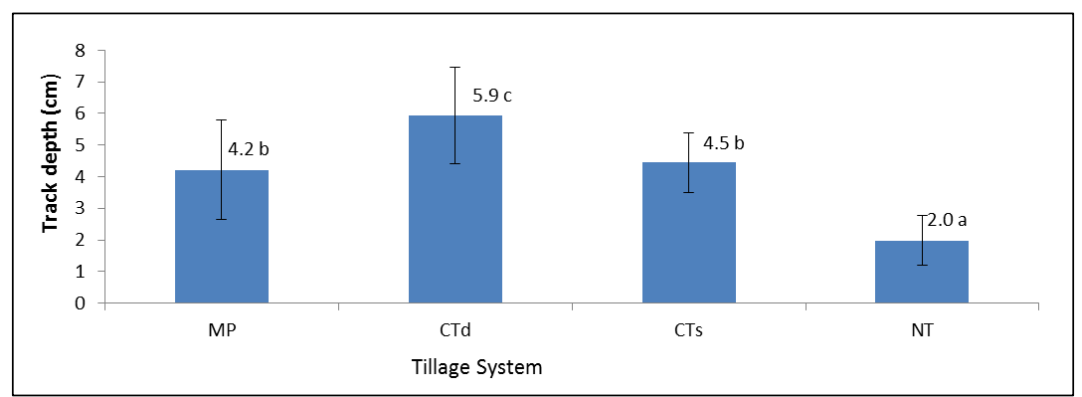

Figure 1. Mean track depth with SD in different tillage systems; N=64; measuring date: $23^{\text {th }}$ March 2017.

Figure 2 shows the soil water conserving effect of the conservation tillage systems CTd, CTs and NT. The soil water content at the measuring time in $23^{\text {th }}$ March 2017 was 
significant higher in CTd, CTs and NT than MP.

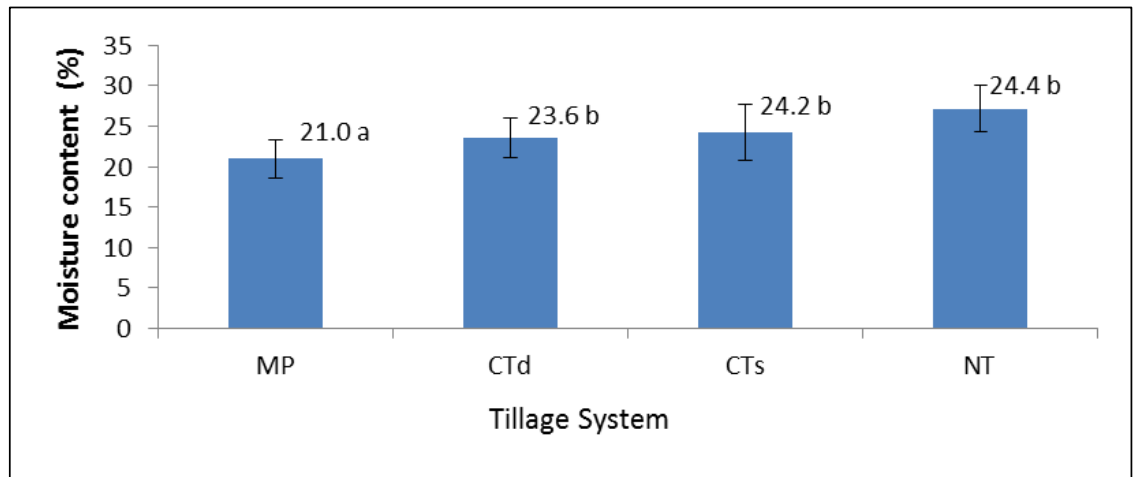

Figure 2. Mean moisture content with SD in different tillage systems; N=28; measuring date: $23^{\text {th }}$ March 2017

\section{Grain yield}

The pre-crops in rotation A (maize) and rotation B (soybean) did not influence the grain yield of winter wheat. Grain yields were affected by the tillage systems (Figure 3 ). The yields were higher in the conservation tillage systems than with MP, which is mainly caused by their better water storage capacity. The highest yield was reached with NT. These results confirm the positive yield effect of conservation tillage systems in dry regions (Pittelkow et al. 2015).

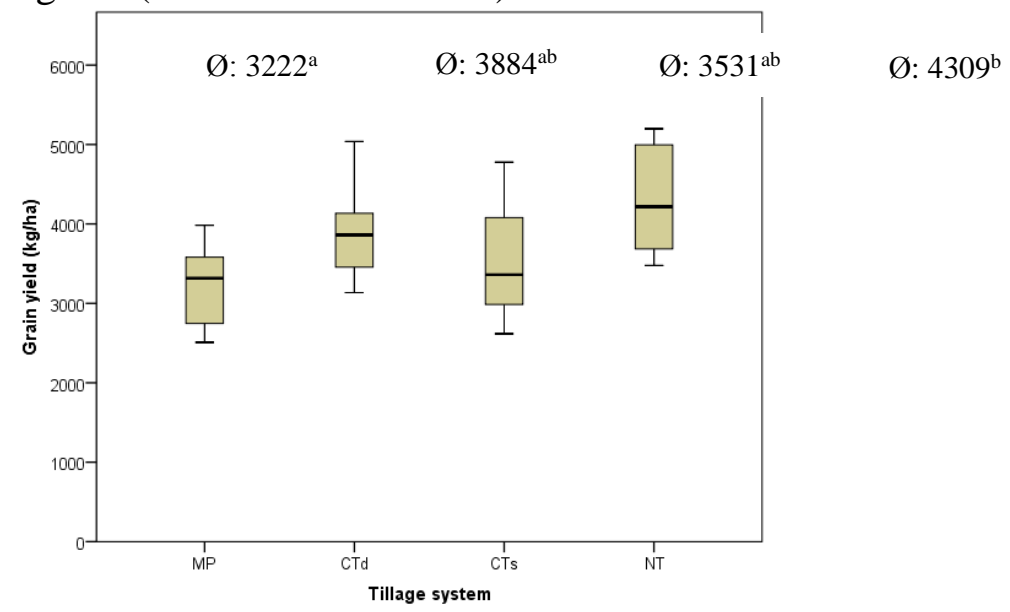

Figure 3. Mean grain yield with box-plots of winter wheat in different tillage systems in the year 2017

\section{CONCLUSIONS}

- The increased soil stability in NT decreased the track depth in the field.

- The stability of the soil is determined by the tillage implement. The deep cultivator application caused a smaller bearing capacity with larger track depths than a mouldboard plough.

- Conservation tillage systems CTd, CTs and NT had a better soil water conserving capacity which results in higher yields in the semi-arid climate region.

\section{ACKNOWLEDGEMENTS}

The authors gratefully acknowledge the technical assistance of Johannes Kemetter, Pia Euteneuer and Susanne Stickler. 


\section{REFERENCES}

Brunotte, J. (2007). Konservierende Bodenbearbeitung als Beitrag zur Minderung von Bodenschadverdichtungen, Bodenerosion, Run off und Mykotoxonbildung im Getreide. Sonderheft Landbauforschung Völkenrode, Bundesforschungsanstalt für Landwirtschaft (FAL), 38116 Braunschweig, Germany.

Neugschwandtner, R. W., Kaul, H.-P., Liebhard, P., \& Wagentristl, H. (2015). Winter wheat yields in a long-term tillage experiment under Pannonian climate conditions. Plant, Soil and Environment 61, 145150 .

Pittelkow, C. M., Liang, X., Linquist, B. A., Van Groenigen, K. J., Lee, J., Lundy, M. E., Van Gestelm, N., Six, J., Venterea, R. T., \& Van Kessel, C. (2015). Productivity limits and potentials of the principles of conservation agriculture. Nature $517,365-368$.

Schick, V. (1991). Mindern von Spurschäden auf Ackerflächen. Forschungsbericht Agrartechnik der Max-Eyth-Gesellschaft (MEG) 202, Dissertation, Christian-Albrechts-Universität Kiel, Germany.

Thaler, S., Eitzinger, J., Trnka, M., \& Dubrovsky, M.( 2012). Impacts of climate change and alternative adaptation options on winter wheat yield and water productivity in a dry climate in Central Europe. The Journal of Agricultural Science, 150, 537-555. 